\title{
MAJOR OIL PLAYS IN UTAH \\ AND VICINITY
}

\author{
QUARTERLY \\ TECHNICAL PROGRESS REPORT
}

Reporting Period

Start Date: January 1, 2003

End Date: March 31, 2003

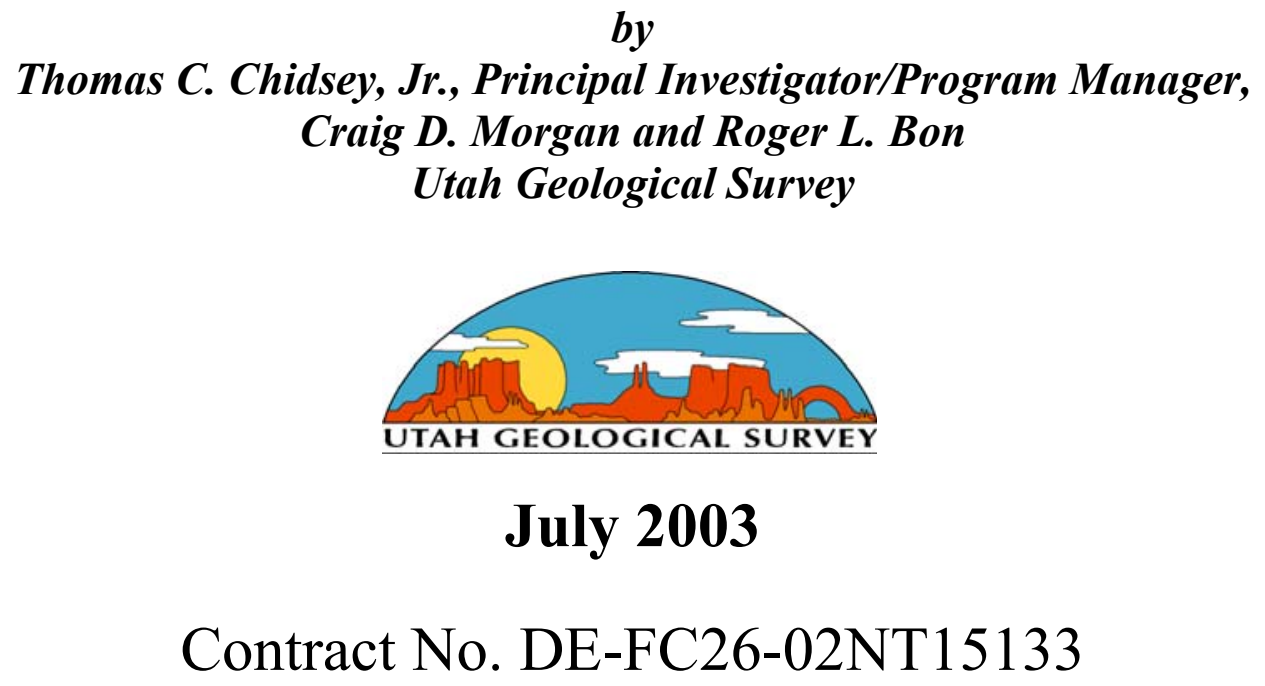

Submitting Organization: Utah Geological Survey

1594 West North Temple, Suite 3110

P.O. Box 146100

Salt Lake City, Utah 84114-6100

Ph.: (801) 537-3300/Fax: (801) 537-3400

Rhonda P. Lindsey, Contract Manager

U.S. Department of Energy

National Petroleum Technology Office

1 West $3^{\text {rd }}$ Street

Tulsa, OK 74103-3532 


\section{DISCLAIMER}

This report was prepared as an account of work sponsored by an agency of the United States Government. Neither the United States Government nor any agency thereof, nor any of their employees, makes any warranty, express or implied, or assumes any legal liability or responsibility for the accuracy, completeness, or usefulness of any information, apparatus, product, or process disclosed, or represents that its use would not infringe privately owned rights. Reference herein to any specific commercial product, process, or service by trade name, trademark, manufacturer, or otherwise does not necessarily constitute or imply its endorsement, recommendation, or favoring by the United States Government or any agency thereof. The views and opinions of authors expressed herein do not necessarily state or reflect those of the United States Government or any agency thereof. 


\title{
MAJOR OIL PLAYS IN UTAH \\ AND VICINITY
}

\author{
QUARTERLY \\ TECHNICAL PROGRESS REPORT
}

Reporting Period

Start Date: January 1, 2003

End Date: March 31, 2003

by

Thomas C. Chidsey, Jr., Principal Investigator/Program Manager,

Craig D. Morgan and Roger L. Bon

Utah Geological Survey

\section{July 2003}

\section{Contract No. DE-FC26-02NT15133}

\author{
Submitting Organization: Utah Geological Survey \\ 1594 West North Temple, Suite 3110 \\ P.O. Box 146100 \\ Salt Lake City, Utah 84114-6100 \\ Ph.: (801) 537-3300/Fax: (801) 537-3400
}

Rhonda P. Lindsey, Contract Manager

U.S. Department of Energy

National Petroleum Technology Office

1 West $3^{\text {rd }}$ Street

Tulsa, OK 74103-3532

US/DOE Patent Clearance is not required prior to the publication of this document. 


\section{CONTENTS}

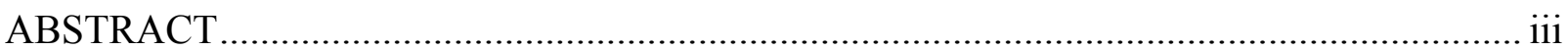

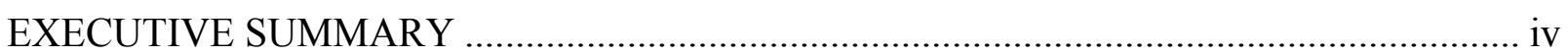

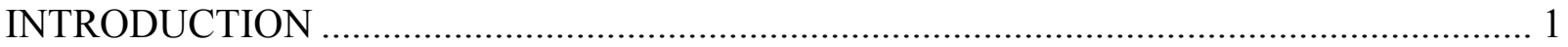

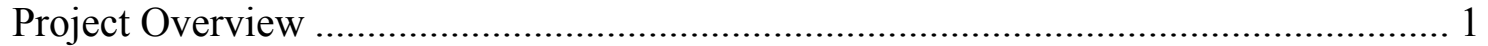

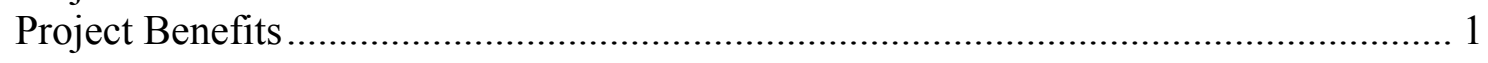

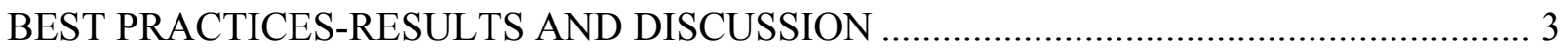

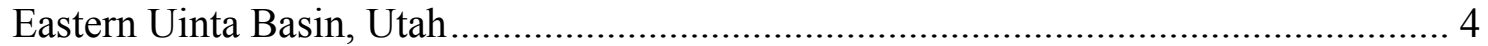

Redwash Field.......................................................................................... 4

Wonsits Valley Field........................................................................................ 5

New Production Practices ............................................................................... 6

Digital database ............................................................................... 6

Manage well stimulation fracture treatments............................................ 6

Oil fingerprinting and water sampling .............................................. 7

Biannual injectivity surveys................................................................. 7

Reservoir mapping ……………………........................................... 7

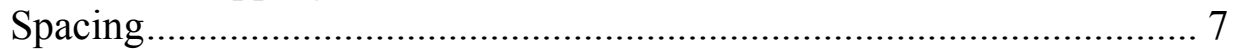

Paradox Basin, Southwestern Colorado................................................................... 7

McClean Field...................................................................................... 8

Optimal Drilling, Development, and Production Practices ............................... 11

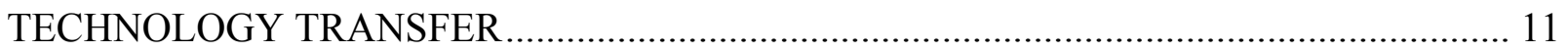

Utah Geological Survey Survey Notes and Internet Web Site...................................... 12

Technical Presentations ........................................................................................... 12

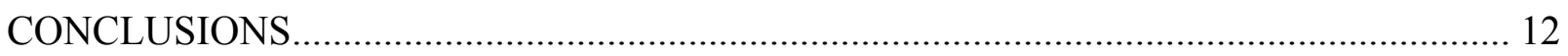

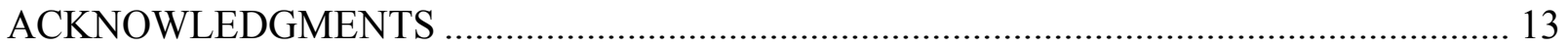

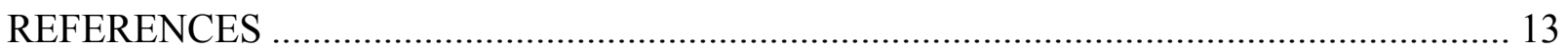




\section{FIGURES}

Figure 1. Major oil-producing provinces of Utah and vicinity - (A) Paradox Basin, (B) Uinta Basin, (C) Utah-Wyoming thrust belt

Figure 2. Block diagram displaying major depositional facies for the Tertiary Green River For-

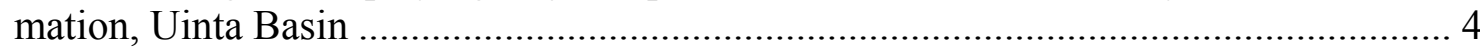

Figure 3. Top of Douglas Creek Member of the Green River Formation, Red Wash field, Uin-

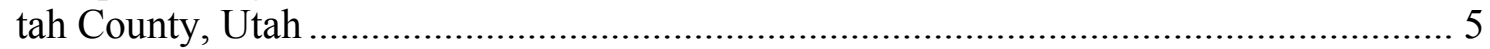

Figure 4. Top of G1 producing zone of the Green River Formation, Wonsits Valley field, Uintah County, Utah ............................................................................................. 6

Figure 5. Block diagram displaying major depositional facies for the Pennsylvanian Paradox Formation, Paradox Basin, Utah and Colorado ........................................................ 8

Figure 6. Map showing project study area and fields within the Ismay and Desert Creek producing trends, Utah and Colorado

Figure 7. Combined top of Desert Creek zone structure and effective porosity map, McClean field, Montezuma County, Colorado 10 


\begin{abstract}
Utah oil fields have produced over 1.2 billion barrels $\left(191\right.$ million $\left.\mathrm{m}^{3}\right)$. However, the 13.7 million barrels $\left(2.2\right.$ million $\mathrm{m}^{3}$ ) of production in 2002 was the lowest level in over 40 years and continued the steady decline that began in the mid-1980s. The Utah Geological Survey believes this trend can be reversed by providing play portfolios for the major oil producing provinces (Paradox Basin, Uinta Basin, and thrust belt) in Utah and adjacent areas in Colorado and Wyoming. Oil plays are geographic areas with petroleum potential caused by favorable combinations of source rock, migration paths, reservoir rock characteristics, and other factors. The play portfolios will include: descriptions and maps of the major oil plays by reservoir; production and reservoir data; case-study field evaluations; summaries of the state-of-the-art drilling, completion, and secondary/tertiary techniques for each play; locations of major oil pipelines; descriptions of reservoir outcrop analogs; and identification and discussion of land use constraints. All play maps, reports, databases, and so forth, produced for the project will be published in interactive, menu-driven digital (web-based and compact disc) and hard-copy formats.

This report covers research activities for the third quarter of the first project year (January 1 through March 31, 2003). This work included gathering field data and analyzing best practices in the eastern Uinta Basin, Utah, and the Colorado portion of the Paradox Basin. Best practices used in oil fields of the eastern Uinta Basin consist of conversion of all geophysical well logs into digital form, running small fracture treatments, fingerprinting oil samples from each producing zone, running spinner surveys biannually, mapping each producing zone, and drilling on 80 -acre (32 ha) spacing. These practices ensure that induced fractures do not extend vertically out of the intended zone, determine the percentage each zone contributes to the overall production of the well, identify areas that may be by-passed by a waterflood, and prevent rapid water breakthrough.

In the eastern Paradox Basin, Colorado, optimal drilling, development, and production practices consist of increasing the mud weight during drilling operations before penetrating the overpressured Desert Creek zone; centralizing treatment facilities; and mixing produced water from pumping oil wells with non-reservoir water and injecting the mixture into the reservoir downdip to reduce salt precipitation, dispose of produced water, and maintain reservoir pressure to create a low-cost waterflood.

During this quarter, technology transfer activities consisted of technical presentations to members of the Technical Advisory Board in Colorado and the Colorado Geological Survey. The project home page was updated on the Utah Geological Survey Internet web site.
\end{abstract}




\section{EXECUTIVE SUMMARY}

Utah oil fields have produced over 1.2 billion barrels $\left(191\right.$ million $\left.\mathrm{m}^{3}\right)$. However, the 13.7 million barrels $\left(2.2\right.$ million $\mathrm{m}^{3}$ ) of production in 2002 was the lowest level in over 40 years and continued the steady decline that began in the mid-1980s. The overall objectives of this study are to: (1) increase recoverable oil from existing field reservoirs, (2) add new discoveries, (3) prevent premature abandonment of numerous small fields, (4) increase deliverability through identifying the latest drilling, completion, and secondary/tertiary techniques, and (5) reduce development costs and risk.

To achieve these objectives, the Utah Geological Survey is producing play portfolios for the major oil producing provinces (Paradox Basin, Uinta Basin, and thrust belt) in Utah and adjacent areas in Colorado and Wyoming. This research is funded by the Preferred Upstream Management Program (PUMPII) of the U.S. Department of Energy, National Petroleum Technology Office (NPTO) in Tulsa, Oklahoma. This report covers research activities for the third quarter of the first project year (January 1 through March 31, 2003). This work included: (1) gathering production, completion, and other field data, (2) analyzing best practices in the eastern Uinta Basin, Utah, and the Colorado portion of the Paradox Basin, and (3) technology transfer activities.

Over 125 fields have been discovered in the major oil provinces with production from 4,300-plus wells. Best practices used in these fields include waterflood, carbon-dioxide flood, gas injection, and horizontal drilling. In the eastern Uinta Basin, production and ultimate recovery from the waterflood units in the Red Wash-Wonsits Valley producing trend are enhanced by the following completion and reservoir management practices: conversion of all geophysical well logs into digital form allowing extensive mapping, correlating, and construction of cross sections; running generally much smaller fracture treatments than in the past to ensure that the induced fractures do not extend vertically out of the intended zone; fingerprinting oil samples from each producing zone to determine the percentage these zones contribute to the overall production of the well; running spinner surveys biannually to determine which zones are producing water; mapping producing zones including oil and water production to determine the advance of the waterfront for each zone and identify areas that may be by-passed by the flood; and drilling on 80-acre (32 ha) spacing to prevent rapid water breakthrough. The estimated secondary recovery using a waterflood program in Red Wash-Wonsits Valley fields is 79.4 million bbls of oil (12.6 million $\left.\mathrm{m}^{3}\right)$.

In the eastern Paradox Basin, Colorado, production and ultimate recovery from the McClean field area is enhanced by the following drilling, development, and production practices: increasing the mud weight to 12.5 pounds $(5.7 \mathrm{~kg})$ during drilling operations before penetrating the overpressured Desert Creek zone; centralizing treatment facilities; and mixing produced water from pumping oil wells with non-reservoir water and injecting the mixture into the reservoir downdip to reduce salt precipitation, dispose of produced water, and maintain reservoir pressure creating a low-cost waterflood.

During this quarter, technology transfer activities included oral technical presentations, describing project goals, tasks, and products, to members of the Technical Advisory Board in Colorado and the Colorado Geological Survey. The project home page was updated on the Utah Geological Survey Internet web site. 


\section{INTRODUCTION}

\section{Project Overview}

Utah oil fields have produced over 1.2 billion barrels (bbls) (191 million $\left.\mathrm{m}^{3}\right)$ (Utah Division of Oil, Gas and Mining, 2003). However, the 13.7 million bbls (2.2 million $\left.\mathrm{m}^{3}\right)$ of production in 2002 was the lowest level in over 40 years and continued the steady decline that began in the mid-1980s (Utah Division of Oil, Gas and Mining, 2002). Proven reserves are relatively high, at 283 million bbls (45 million $\mathrm{m}^{3}$ ) (Energy Information Administration, 2001). With higher oil prices now prevailing, secondary and tertiary recovery techniques should boost future production rates and ultimate recovery from known fields.

Utah's drilling history has fluctuated greatly due to discoveries, oil price trends, and changing exploration targets. During the boom period of the early 1980s, activity peaked at over 500 wells per year. Sustained high prices are likely to entice less risk-averse exploration investment (more wildcats), resulting in new discoveries.

Utah still contains large areas that are virtually unexplored. There is significant potential for increased recovery from existing fields by employing improved reservoir characterization and the latest drilling, completion, and secondary/tertiary technologies. New exploratory targets may be identified from three-dimensional (3D) seismic surveys. Development of potential prospects is within the economic and technical capabilities of both major and independent operators.

The primary goal of this study is to increase recoverable oil reserves from existing field reservoirs and new discoveries by providing play portfolios for the major oil producing provinces (Paradox Basin, Uinta Basin, and thrust belt) in Utah and adjacent areas in Colorado and Wyoming (figure 1). These play portfolios will include: descriptions (such as stratigraphy, diagenetic analysis, tectonic setting, reservoir characteristics, trap type, seal, and hydrocarbon source) and maps of the major oil plays by reservoir; production and reservoir data; case-study field evaluations; summaries of the state-of-the-art drilling, completion, and secondary/tertiary techniques for each play; locations of major oil pipelines; and descriptions of reservoir outcrop analogs for each play. Also included will be land use constraints to development such as wilderness or roadless areas, and national parks within oil plays.

\section{Project Benefits}

The overall benefits of this multi-year project will be enhanced petroleum production in the Rocky Mountain region. Specifically, the benefits expected from the project are:

(1) increasing oil production and reserves by improved reservoir characterization,

(2) preventing premature abandonment of numerous small fields in the Paradox and Uinta Basins,

(3) increasing recoverable reserves by identifying the type of untapped compartments created by reservoir heterogeneity (for example, diagenesis and rapid facies changes), 


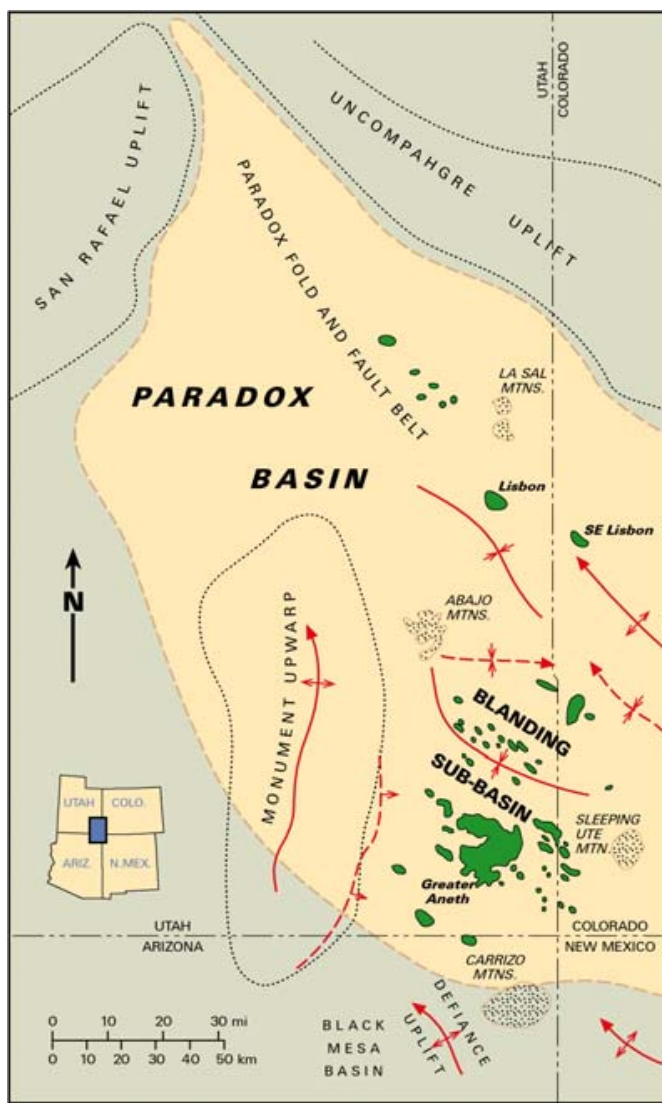

A

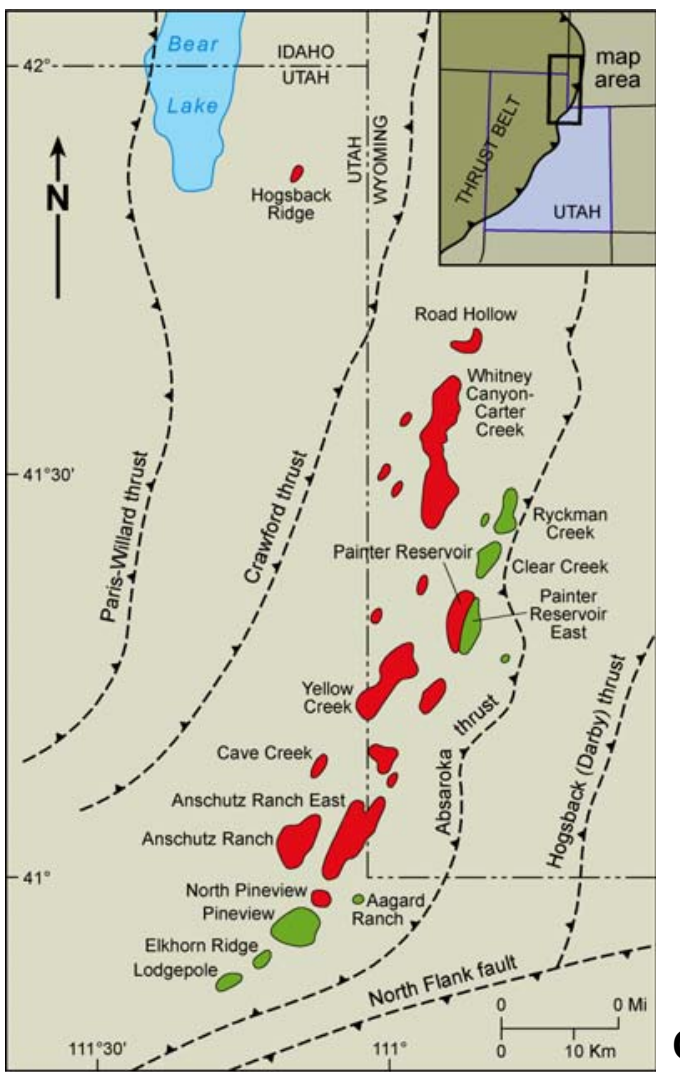

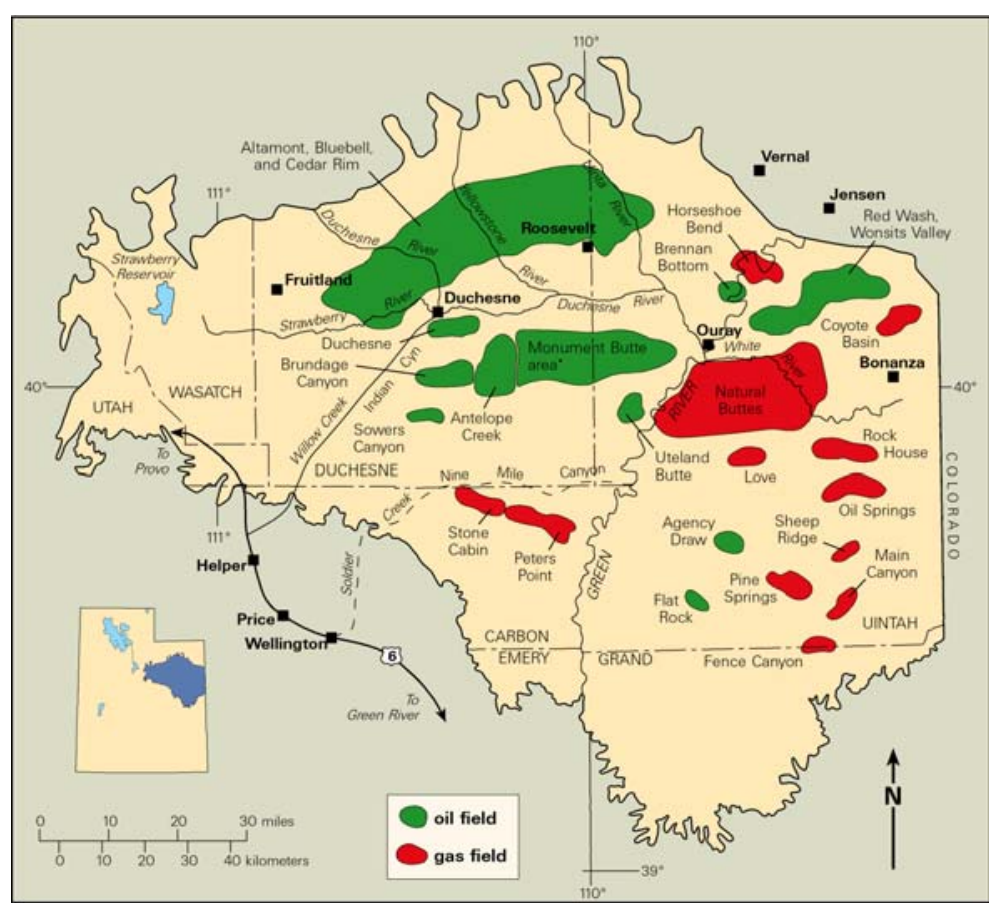

B

Figure 1. Major oil-producing provinces of Utah and vicinity. (A) Oil and gas fields in the Paradox Basin of Utah and Colorado. (B) Oil and gas fields in the Uinta Basin of Utah. (C) Oil and gas fields, uplifts, and major thrust faults in the UtahWyoming thrust belt. 
(4) increasing deliverability through identifying the latest drilling, completion, and secondary/tertiary techniques,

(5) identifying reservoir trends for field extension drilling and stimulating exploration in producing fairways,

(6) encouraging technology used in other identified basins or trends with similar types of reservoirs,

(7) reducing development costs and risk by reducing the number of wells needed to successfully drain the reservoir,

(8) allowing limited energy investment dollars to be used more productively, and

(9) increasing royalty income to the Federal Government; Utah, Wyoming, and Colorado state and local governments; the Navajo Nation and Ute Mountain Ute Indian Nation; and fee owners.

The Utah play portfolios produced by this project will provide an easy-to-use geologic, engineering, and geographic reference to help petroleum companies plan exploration and landacquisition strategies. These portfolios may also help pipeline companies plan future facilities and pipelines. Other users of the portfolios will include petroleum engineers, petroleum land specialists, landowners, bankers and investors, economists, utility companies, manufacturers, county planners, and numerous government agencies.

The results of this project will be transferred to industry and other interested parties through establishment of Technical Advisory and Stake Holder Boards, an industry outreach program, and technical presentations at national and regional professional meetings. All of this information will be made public (1) through the Utah Geological Survey (UGS) Internet web site, (2) as an interactive, menu-driven digital product on compact disc, and (3) as hard copy publications in various technical or trade journals.

\section{BEST PRACTICES-RESULTS AND DISCUSSION}

Over 125 fields have been discovered in the Paradox Basin, Uinta Basin, and thrust belt with production from 4,300-plus wells. Best practices used in these fields include waterflood, carbon-dioxide flood, gas injection, and horizontal drilling. Data were collected from the files of the Colorado Oil and Gas Conservation Commission for selected fields in the Colorado portion of the Paradox Basin. The purpose of this data collection was to help determine the best drilling, completion, and secondary/tertiary recovery techniques for these and similar fields. Specific completion and reservoir management practices were described by various operators of oil fields in both the Paradox and Uinta Basins. 


\section{Eastern Uinta Basin, Utah}

The Uinta Basin is a major depositional and structural basin that subsided and contained large lakes during the early Cenozoic (figure 1B). The Green River and Wasatch Formations, consisting of over 11,000 feet $(3,600 \mathrm{~m})$ of Eocene through Paleocene sedimentary rocks, accumulated in and around the Uinta and Flagstaff lakes in an intertonguing relationship (figure 2). Major depositional facies are alluvial, marginal lacustrine, and open lacustrine. Hydrocarbons are typically trapped in fluvial-deltaic, distributary-channel, bars, and beach sandstone, which pinch out regionally updip or across subtle anticlinal noses. Fractures often play an important role in increasing reservoir permeability.

Oil production in the Uinta Basin can be divided into three primary producing trends: Red Wash-Wonsits Valley, Altamont-Bluebell, and Monument Butte in the eastern, northcentral, and south-central parts of the basin, respectively (figure 1B). The Red Wash-Wonsits Valley trend is discussed here.

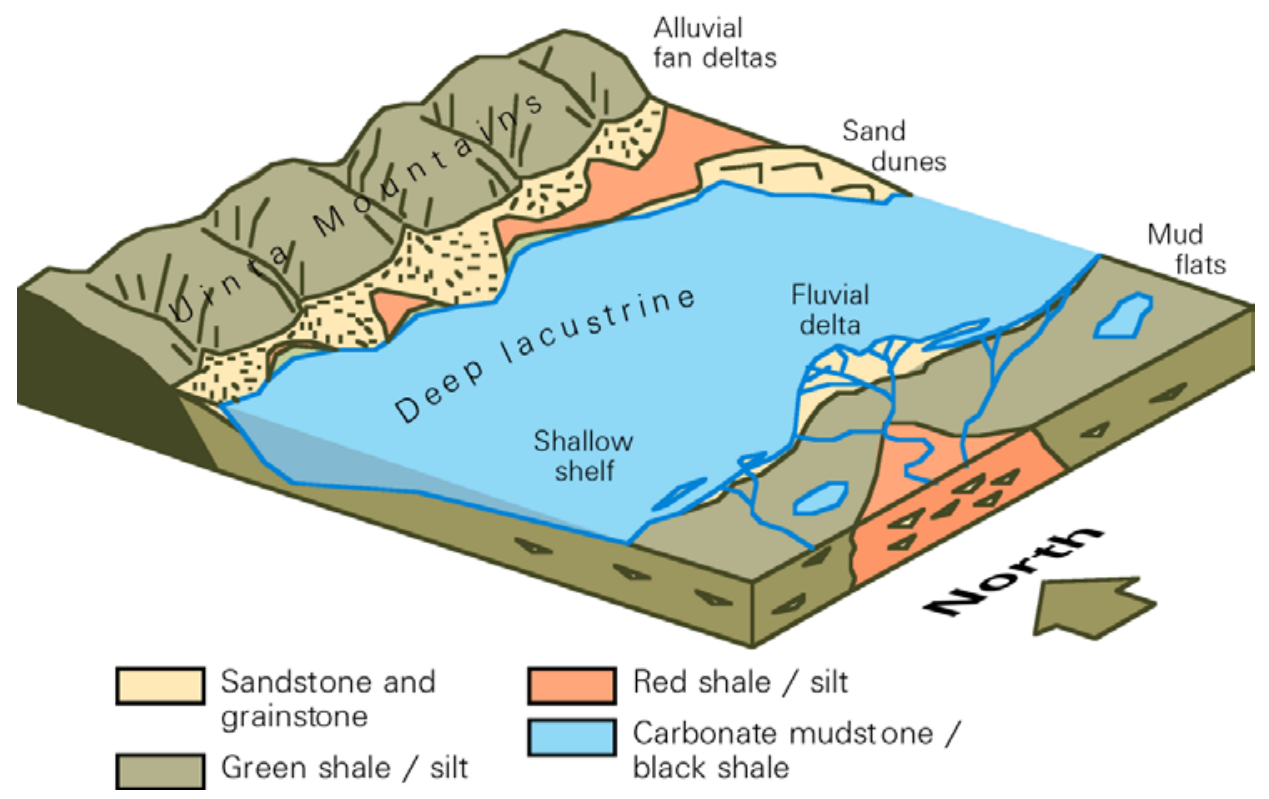

Figure 2. Block diagram displaying major depositional facies for the Tertiary Green River Formation, Uinta Basin.

\section{Redwash Field}

Redwash field, Uintah County, Utah, is a stratigraphic pinch-out across a structural nose (figure 3) that produces primarily from fluvial-deltaic sandstone in the Green River Formation (Castle, 1990). The net reservoir thickness is 170 feet $(50 \mathrm{~m})$, which extends over a 31,000acre $(12,500 \mathrm{ha})$ area. Porosity ranges from 10 to 22 percent with an average of 42 millidarcies (md) of permeability (Schuh, 1993).

Redwash field was discovered in 1951 with the completion of the California Oil Co. (Chevron) Red Wash Unit No. 1 well, NE1/4NE1/4 section 26, T. 7 S., R. 23 E., Salt Lake Base Line and Meridian (SLBL\&M); initial flowing potential was 339 bbls of oil per day (BOPD) $\left(54 \mathrm{~m}^{3}\right)$ and 698 thousand cubic feet of gas per day (MCFGPD) (20 MCMPD). The field currently has 193 producing (or shut-in) wells. The well spacing is 40 to 80 acres (16-32 ha). The present reservoir field pressure ranges from 400 to 2,000 pounds per square inch (psi) $(2,800$ $13,800 \mathrm{kpa})$. 


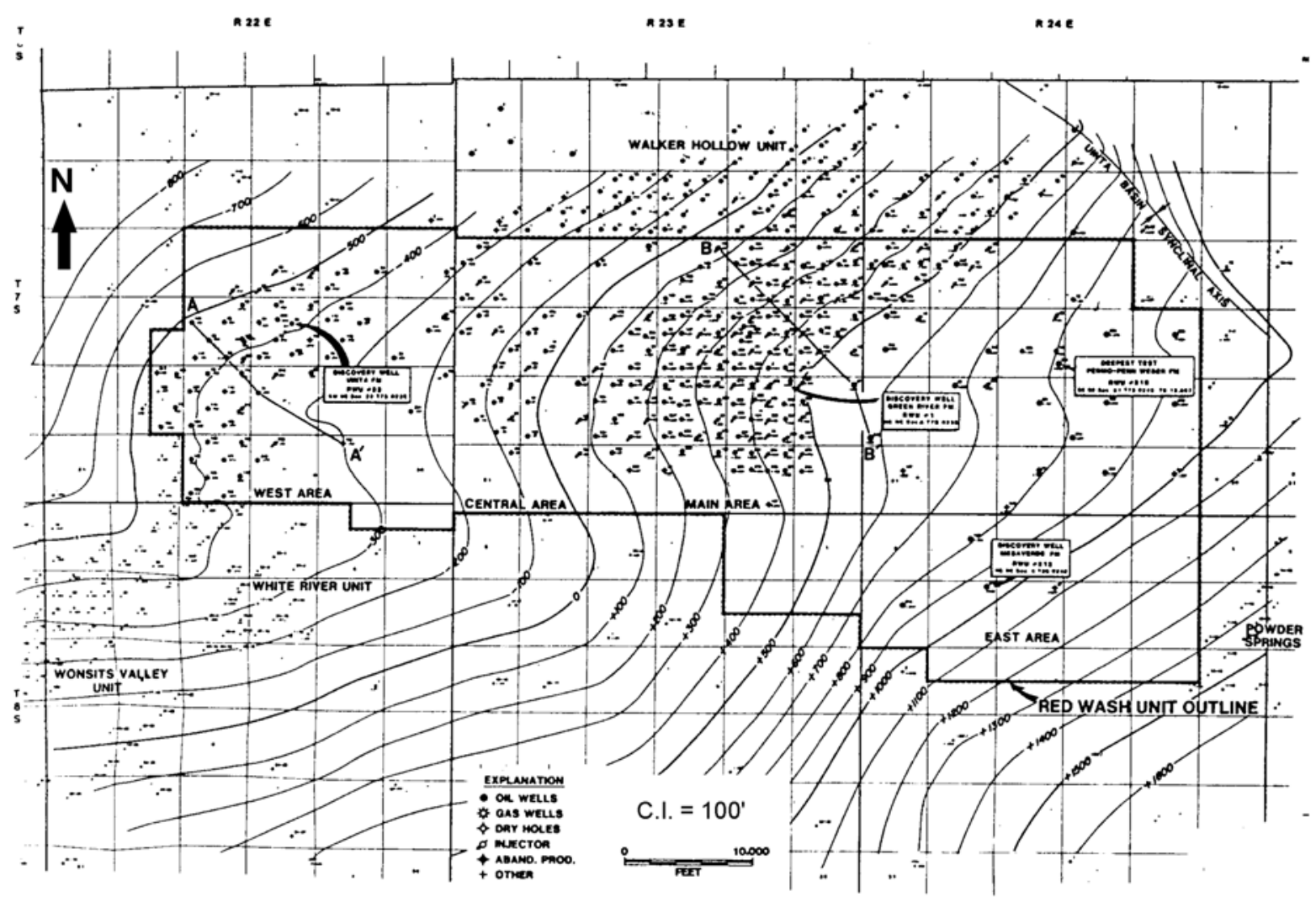

Figure 3. Structure map on top of Douglas Creek Member of the Green River Formation, Red Wash field, Uintah County, Utah (after Schuh, 1993).

Cumulative production as of March 1, 2003, was 80,791,477 bbls of oil $(12,845,845$ $\left.\mathrm{m}^{3}\right)$, 341.5 billion cubic feet of gas (BCFG) (9.7 BCMG), and over 310 million bbls of water $\left(50\right.$ million $\left.\mathrm{m}^{3}\right)$ (Utah Division of Oil, Gas and Mining, 2003). The original estimated primary recovery was 53 million bbls of oil $\left(8.4\right.$ million $\left.\mathrm{m}^{3}\right)$ and 300 BCFG (8.5 BCMG) (Schuh, 1993). The estimated secondary recovery was 53 million bbls of oil $\left(8.4\right.$ million $\left.\mathrm{m}^{3}\right)$ using a waterflood program (Schuh, 1993).

\section{Wonsits Valley Field}

Wonsits Valley field, Uintah County, Utah, is a stratigraphic trap due to lateral facies changes (figure 4) that produces from medium-grained, quartz sandstone and fine-grained, sandy, ostracodal limestone deposited in a high-energy, barrier-beach complex of the Green River Formation (Castle, 1990). The net reservoir thickness is 90 feet $(30 \mathrm{~m})$, which extends over a 6,240-acre $(2,530 \mathrm{ha})$ area. Porosity and permeability averages 12 percent and $22 \mathrm{md}$, respectively (Schuh, 1993).

Wonsits Valley field was discovered in 1962 with the completion of the Gulf Oil Co. Stout Federal Unit No. 1 well, NE1/4NE1/4 section 8, T. 8 S., R. 22 E., SLBL\&M; initial flowing potential was 13 BOPD $\left(2 \mathrm{~m}^{3}\right)$ and 8 bbls of water per day $\left(1 \mathrm{~m}^{3}\right)$. The field currently has 245 producing (or shut-in) wells. The well spacing is 40 acres (16 ha). The present reservoir field pressure is $2,500 \mathrm{psi}(17,200 \mathrm{kpa})$. 


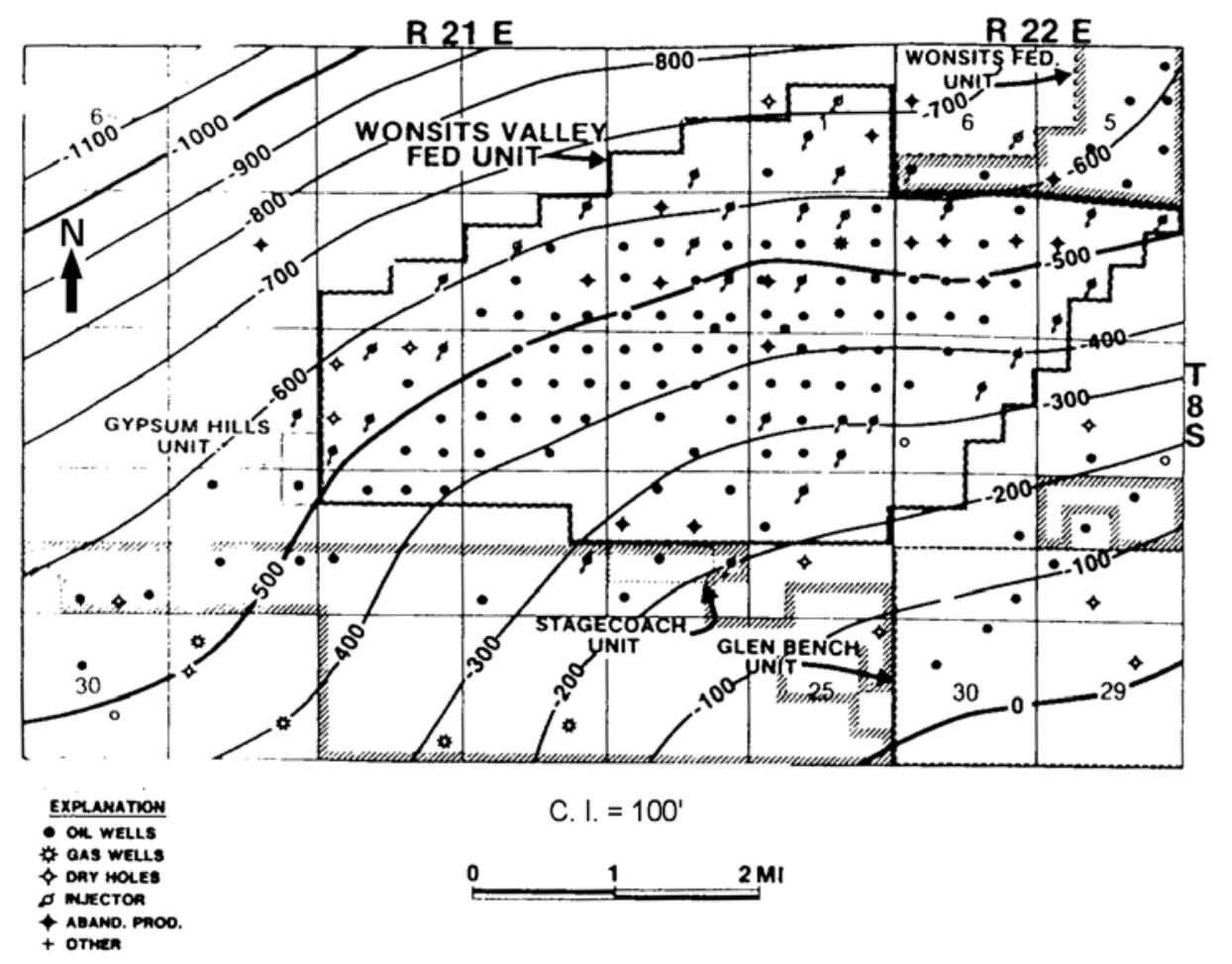

Figure 4. Structure map on top of $G 1$ producing zone of the Green River Formation, Wonsits Valley field, Uintah County, Utah (after Schuh, 1993).

Cumulative production as of March 1, 2003, was 48,367,595 bbls of oil $\left(7,690,448 \mathrm{~m}^{3}\right)$, 64 BCFG (2 BCMG), and over 169 million bbls of water $\left(27\right.$ million $\mathrm{m}^{3}$ ) (Utah Division of Oil, Gas and Mining, 2003). The original estimated primary recovery was 21.6 million bbls of oil $\left(3.4\right.$ million $\mathrm{m}^{3}$ ) (Schuh, 1993). The estimated secondary recovery was 26.4 million bbls of oil (4.2 million $\mathrm{m}^{3}$ ) using a waterflood program similar to Redwash field (Schuh, 1993).

\section{New Production Practices}

To enhance production and the ultimate recovery from the waterflood units in Redwash and Wonsits Valley fields, the following completion and reservoir management practices are now being employed by the current operator (Russ Griffin, Questar Exploration and Production Co., verbal communication, 2003).

Digital database: All geophysical well logs are converted into digital form allowing extensive mapping, correlating, and construction of cross sections with minimal effort. Well histories for all the wells were entered into a database allowing rapid access and review of decades of activity in any well.

Manage well stimulation fracture treatments: Common practice in the past was to apply massive or large fracture treatments as part of a well completion program. Large fracture treatments have resulted in vertical communication between zones greatly reducing the effectiveness of the flood. Fracture treatments are now generally much smaller. The fracture treatments are designed to ensure that the induced fractures do not extend vertically out of the intended zone especially if the well is going to be an injector. 
Oil fingerprinting and water sampling: Oil samples are collected and fingerprinted from each producing zone. Most wells are producing from multiple zones; each zone will flood at a different rate. With fingerprinting a sample can be collected at the wellhead to determine the percentage of production contribution each zone is making without pulling tubing and running production logs. If a zone is contributing nothing, then that zone is probably flooded and can be cemented off. Water samples are also collected from individual zones to determine the chemical characteristics and resistivity. For the waterflood programs, the operator uses fresh water from the Green River in the new areas of the fields and produced water in the older sections.

Biannual injectivity surveys: Spinner surveys are run twice a year in the injection wells to determine which zones the water is entering.

Reservoir mapping: Each producing zone is mapped (structure and isopach) including oil and water production. By monitoring the oil and water contribution from each zone and plotting these data on the maps, the operator can see the advance of the waterfront for each zone and identify areas that may be by-passed by the flood.

Spacing: Originally, part of Red Wash field was completed on 40-acre (16 ha) spacing. There is an east-to-west permeability trend through the field that is related to the regional fracture trends. The early operators experienced rapid water breakthrough in many of the wells during the waterflood program with 40 -acre (16 ha) spacing. An 80-acre (32 ha) spacing works best at Red Wash; many of the wells in the 40 -acre (16 ha) spaced area have been plugged, increasing the spacing between wells.

\section{Paradox Basin, Southwestern Colorado}

The Paradox Basin is located mainly in southeastern Utah and southwestern Colorado (figure 1). The Paradox Basin is an elongate, northwest-southeast-trending evaporitic basin that predominately developed during the Pennsylvanian (Desmoinesian), about 330 to 310 million years ago. The Uncompahgre Highlands in eastern Utah and western Colorado initially formed as the westernmost range during the mountain-building period that formed the Ancestral Rockies. The Uncompahgre Highlands (uplift) is bounded along the southwestern flank by a large basement-involved, high-angle reverse fault identified from geophysical seismic surveys and exploration drilling. As the highlands rose, an accompanying depression, or foreland basin, formed to the southwest - the Paradox Basin. Rapid subsidence, particularly during the Pennsylvanian and then continuing into the Permian, accommodated large volumes of evaporitic and marine sediments that intertongued with non-marine arkosic material shed from the highland area to the northeast (Hintze, 1993). The Paradox Basin is surrounded by other uplifts and basins that formed during the Late Cretaceous-early Tertiary Laramide orogeny.

The Paradox Basin can generally be divided into two areas: the Paradox fold and fault belt in the north, and the Blanding sub-basin in the south-southwest (figure 1A). Most oil production is in the Blanding sub-basin. The relatively undeformed Blanding sub-basin developed on a shallow-marine shelf that locally contained algal-mound and other carbonate buildups in a subtropical climate (figure 5). 


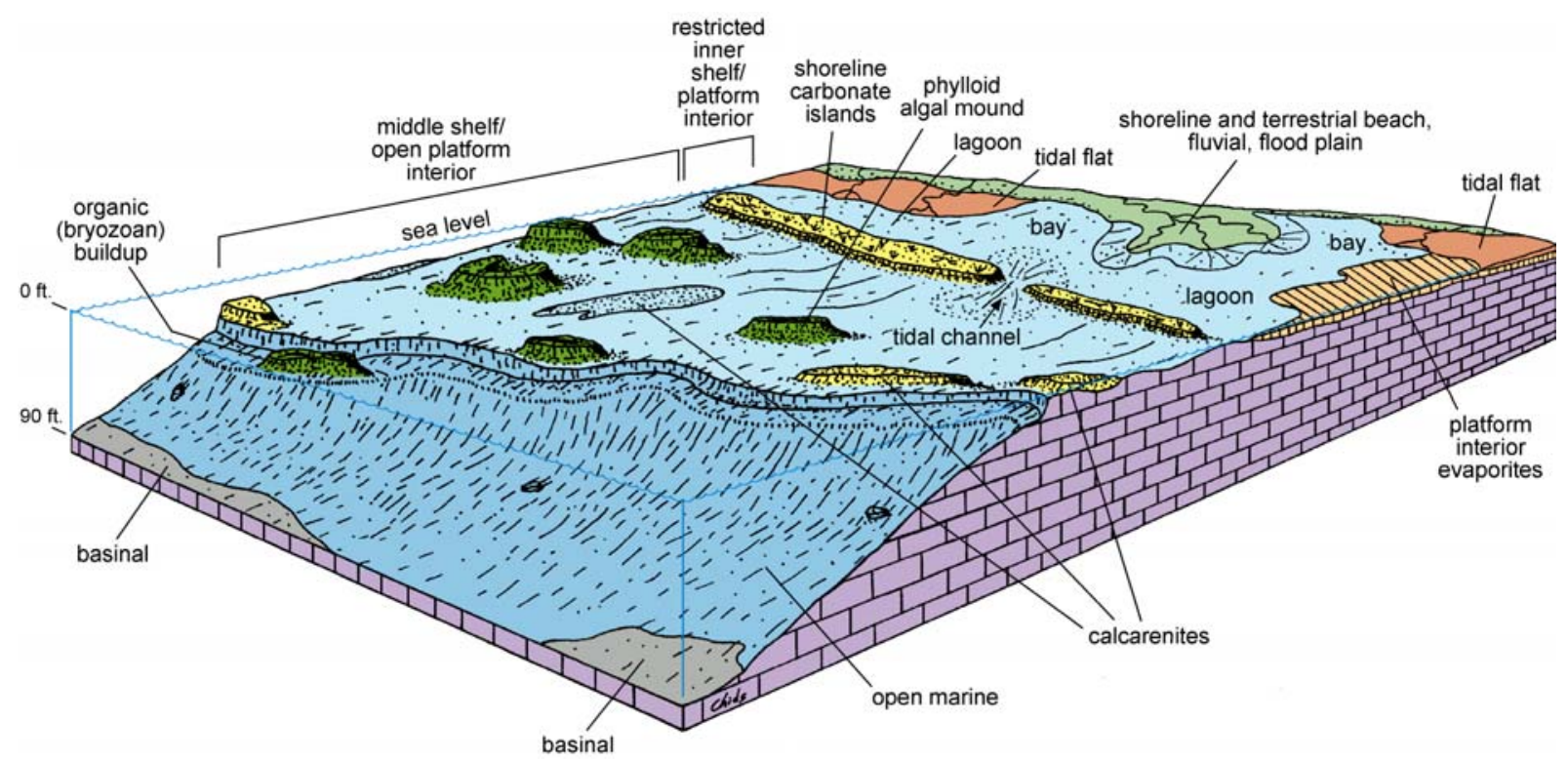

Figure 5. Block diagram displaying major depositional facies for the Pennsylvanian Paradox Formation, Paradox Basin, Utah and Colorado.

The two main producing zones are informal zones of the Paradox Formation, the Ismay and the Desert Creek. The Ismay zone is dominantly limestone comprising equant buildups of phylloid-algal material with locally variable small-scale subfacies capped by anhydrite. The Ismay produces oil from fields in the southern Blanding sub-basin (figure 6). The Desert Creek zone is dominantly dolomite comprising regional nearshore shoreline trends with highly aligned, linear facies tracts. The Desert Creek produces oil in fields in the central Blanding sub-basin (figure 6). Both the Ismay and Desert Creek buildups generally trend northwestsoutheast. Various facies changes and extensive diagenesis have created complex reservoir heterogeneity within these two diverse zones.

\section{McClean Field}

McClean (Cutthroat) field, Montezuma County, Colorado, is an elongate, northnorthwest-trending carbonate buildup that forms an updip porosity pinch-out in the lower Desert Creek zone (figure 7) (Mickel, 1978). The producing units vary from porous, dolomitized, phylloid-algal (Kanasphyllum) boundstone to packstone (Matheny and Longman, 1996). The net reservoir thickness is 30 feet $(10 \mathrm{~m})$, which extends over a 1,300-acre (526 ha) area. Porosity averages 11 percent; permeability is highly variable (Mickel, 1978).

McClean field was discovered in 1974 with the completion of the Mountain Fuel Supply No. 2 well, SW1/4NE1/4 section 15, T. 37 N., R. 19 W.; initial flowing potential was 504 BOPD $\left(80 \mathrm{~m}^{3}\right), 713 \mathrm{MCFGPD}(20 \mathrm{MCMPD})$, and $528 \mathrm{bbls}$ of water per day $\left(84 \mathrm{~m}^{3}\right)$. The field currently has six producing (or shut-in) wells. The original reservoir field pressure was 3,577 psi $(24,663 \mathrm{kpa})$ (Colorado Oil and Gas Conservation Commission, 1985b).

Cumulative production as of May 1, 2003, was 4,512,114 bbls of oil $\left(717,426 \mathrm{~m}^{3}\right)$ and 5.9 BCFG (0.2 BCMG) (Colorado Oil \& Gas Conservation Commission records). Ultimate recovery from good wells is estimated to be as high as 1 million bbls of oil $\left(0.2\right.$ million $\left.\mathrm{m}^{3}\right)$ and 5 BCFG (0.1 BCMG) (Phil Moffit, Questar Exploration and Production Co., verbal communication, 2003). 


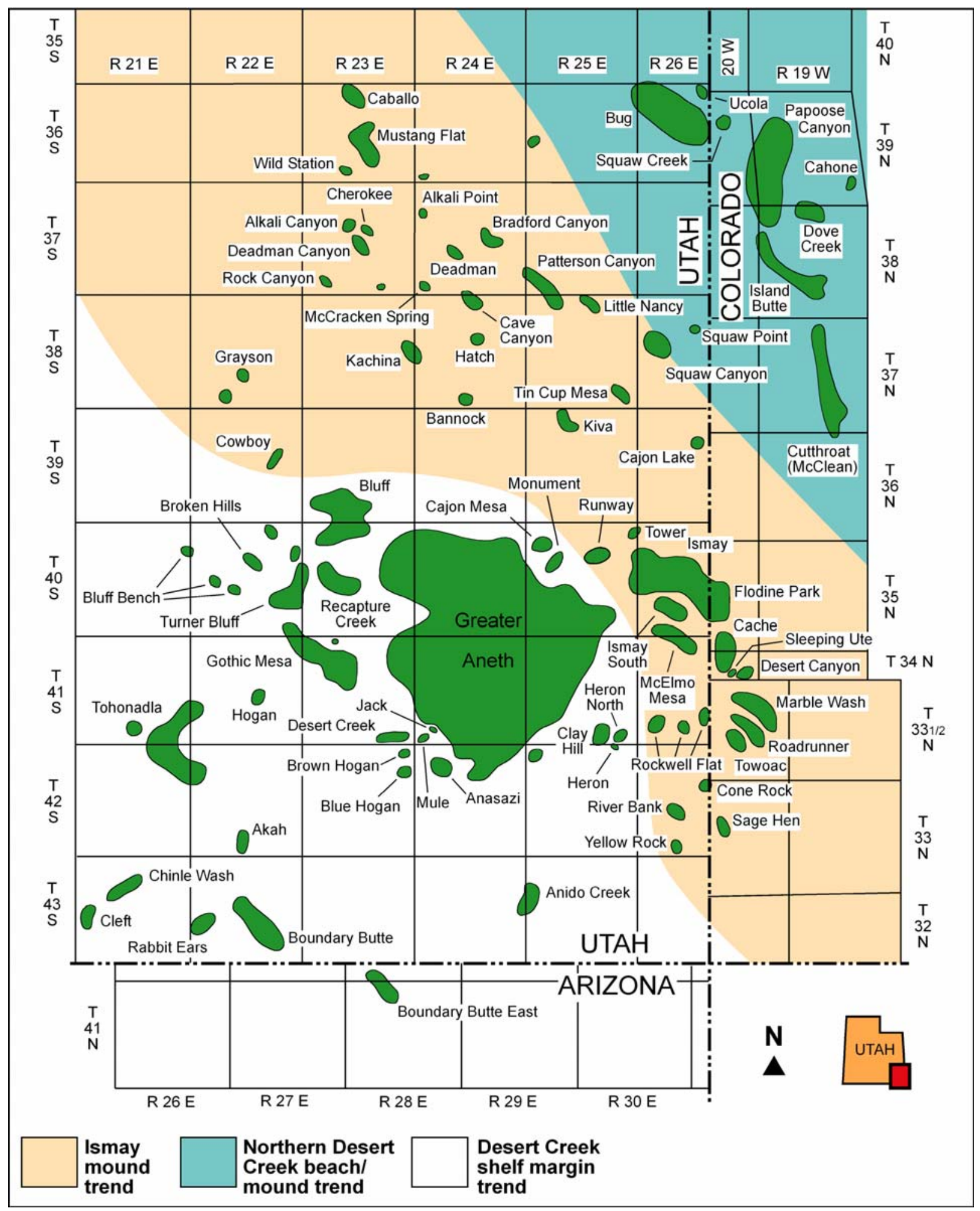

Figure 6. Map showing fields within the Ismay and Desert Creek producing trends in the Blanding sub-basin, Utah and Colorado. Fields shown in the white area of the map, including the giant Greater Aneth field, produce primarily from the Desert Creek zone on the shelf margin of the Paradox Basin. 


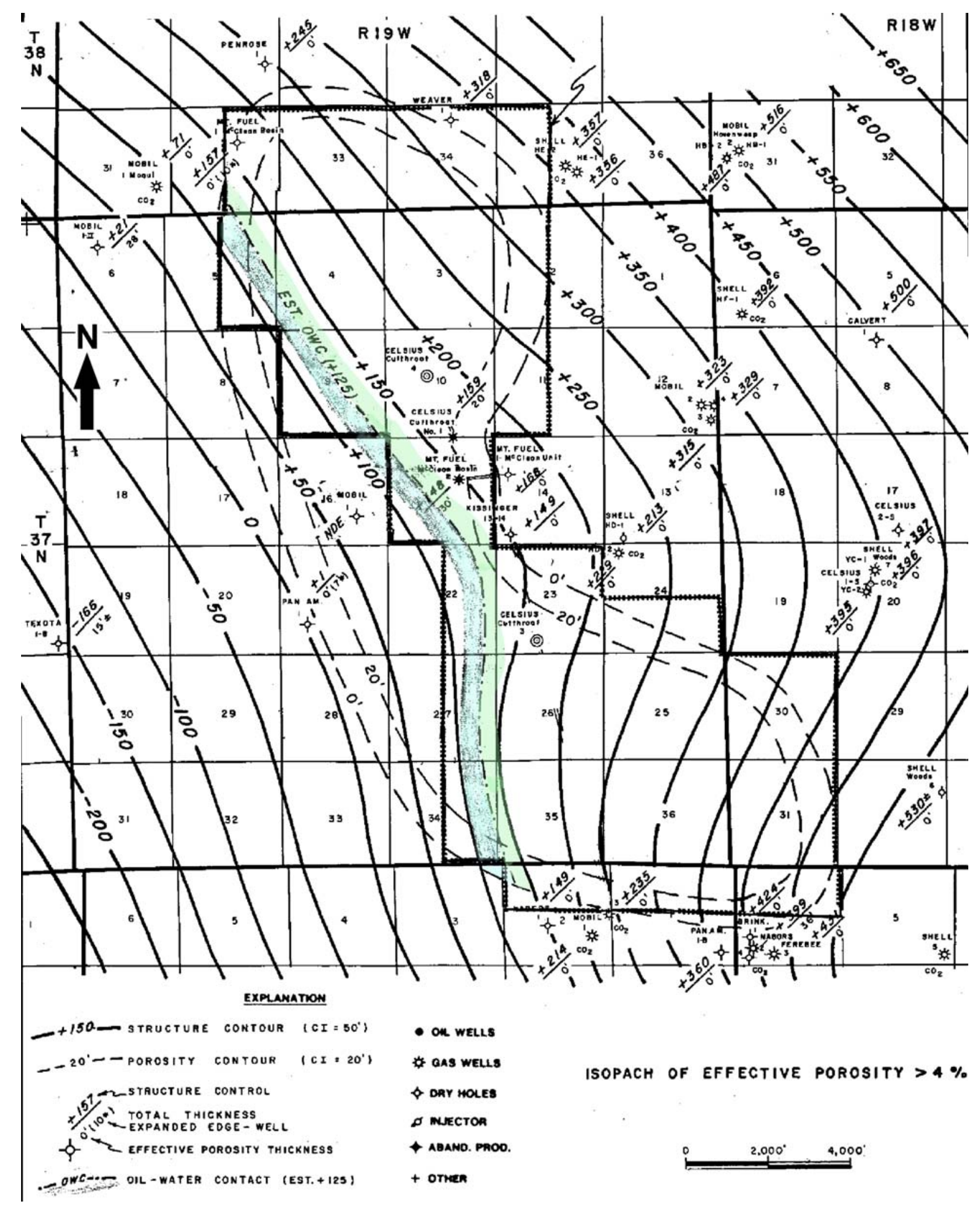

Figure 7. Combined top of Desert Creek zone structure and effective porosity map, McClean field, Montezuma County, Colorado (after Colorado Oil and Gas Conservation Commission, 1985a). 


\section{Optimal Drilling, Development, and Production Practices}

The Desert Creek zone is overpressured by as much as $1,500 \mathrm{psi}(10,300 \mathrm{kpa})$ in the McClean area. After penetrating potential lost-circulation zones in the shallow (950 to 1,700 feet $[320-570 \mathrm{~m}]$ ) Jurassic Carmel Formation and Wingate Sandstone, the mud weight must be increased to 12.5 pounds $(5.7 \mathrm{~kg}$ ) above the Desert Creek (Michel, 1978).

The well spacing for McClean field was originally set at 160 acres (65 ha), but was later changed to general field rules as a result of the formation of a federal exploration unit due to problems associated with rough topography, archeological findings, and competitive drilling locations. The oil is highly volatile, $46.2^{\circ}$ API gravity and a gas-to-oil ratio of 1,622 , requiring an expensive, centralized treatment facility to increase recovery (Colorado Oil and Gas Conservation Commission, 1985a, 1987).

To enhance the ultimate recovery from McClean field, fresh water is injected down the tubing and casing to keep the natural brine from precipitating salts. In addition, produced water from pumping oil wells is used to create a mixture with non-reservoir water. This mixture of water is injected into the reservoir downdip to (1) again, reduce salt precipitation, (2) dispose of produced water, and (3) maintain reservoir pressure thus creating a low-cost waterflood (Phil Moffit, Questar Exploration and Production Co., verbal communication, 2003).

\section{TECHNOLOGY TRANSFER}

The UGS is the Principal Investigator and prime contractor for the PUMPII project and three government-industry cooperative petroleum-research projects. These projects are designed to improve recovery, development, and exploration of the nation's oil and gas resources through use of better, more efficient technologies. The projects involve detailed geologic and engineering characterization of several complex heterogeneous reservoirs. Two Class II Oil projects include practical oil-field demonstrations of selected technologies in the Paradox Basin. The third project involves establishing a log-based correlation scheme for the Tertiary Green River Formation in the southwestern Uinta Basin to help identify new plays and improve the understanding of producing intervals. The DOE and multidisciplinary teams from petroleum companies, petroleum service companies, universities, private consultants, and state agencies are co-funding the three projects.

All play maps, reports, databases, and so forth, produced for the PUMPII project will be published in interactive, menu-driven digital (web-based and compact disc) and hard-copy formats by the Utah Geological Survey and presented to the petroleum industry. Syntheses and highlights will be submitted to refereed journals, as appropriate, such as the American Association of Petroleum Geologists (AAPG) Bulletin and Journal of Petroleum Technology, and to trade publications such as the Oil and Gas Journal. This information will also be released through the UGS periodical Survey Notes and on the UGS project Internet web page.

The technology-transfer plan includes a Technical Advisory Board and a Stake Holders

Board. The Technical Advisory Board advises the technical team on the direction of study, reviews technical progress, recommends changes and additions to the study, and provides data. The Technical Advisory Board is composed of field operators from the oil-producing provinces of Utah that may also extend into Wyoming or Colorado. This board ensures direct communi- 
cation of the study methods and results to the operators. The Stake Holders Board is composed of groups that have a financial interest in the study area including representatives from the State of Utah (School and Institutional Trust Lands Administration and Utah Division of Oil, Gas and Mining) and the Federal Government (Bureau of Land Management and Bureau of Indian Affairs). The members of the Technical Advisory and Stake Holders Boards receive all quarterly technical reports and copies of all publications, and other material resulting from the study. They will also provide field and reservoir data, especially data pertaining to best practices.

\section{Utah Geological Survey Survey Notes and Internet Web Site}

Survey Notes provides non-technical information on contemporary geologic topics, issues, events, and ongoing UGS projects to Utah's geologic community, educators, state and local officials and other decision makers, and the public. Survey Notes is published three times yearly. Single copies are distributed free of charge and reproduction (with recognition of source) is encouraged.

The UGS maintains a web site on the Internet, http://geology.utah.gov. The UGS site includes a page under the heading Utah Geology/Oil and Energy, which describes the UGS/ DOE cooperative studies (PUMPII, Paradox Basin [two projects], Ferron Sandstone, Bluebell field, Green River Formation), and has a link to the DOE web site. Each UGS/DOE cooperative study also has its own separate page on the UGS web site. The PUMPII project page, http://geology.utah.gov/emp/pump/index.htm, contains: (1) a project location map, (2) a description of the project, (3) a reference list of all publications that are a direct result of the project, and (4) quarterly technical progress reports.

\section{Technical Presentations}

The following technical presentations were made during the quarter as part of the technology transfer activities:

"Major Oil Plays of Utah and Vicinity," by Thomas C. Chidsey, Jr., describing project goals, tasks, and products, to (1) the members of the Technical Advisory Board in Colorado, and (2) the Colorado Geological Survey, February 2003. Maps, cross sections, diagrams, and other information were part of the presentations.

\section{CONCLUSIONS}

A combination of depositional and structural events created the right conditions for oil generation and trapping in the major oil producing provinces (Paradox Basin, Uinta Basin, and thrust belt) in Utah and adjacent areas in Colorado and Wyoming. Oil plays are specific geographic areas with petroleum potential due to favorable source rock, migration paths, reservoir characteristics, and other factors.

To enhance production and ultimate recovery from the waterflood units in the Red Wash-Wonsits Valley producing trend of the eastern part of the Uinta Basin, the following 
completion and reservoir management practices should be employed: convert all geophysical well logs into digital form allowing extensive mapping, correlating, and construction of cross sections; conduct generally much smaller fracture treatments than in the past to ensure that the induced fractures do not extend vertically out of the intended zone; fingerprint oil samples from each producing zone to determine the percentage these zones contribute to the overall production of the well; run spinner surveys biannually to determine which zones are producing water; map producing zones including oil and water production to determine the advance of the waterfront for each zone and identify areas that may be by-passed by the flood; and drill on 80-acre (32 ha) spacing to prevent rapid water breakthrough. The estimated secondary recovery using a waterflood program in Red Wash-Wonsits Valley fields is 79.4 million bbls of oil (12.6 million $\left.\mathrm{m}^{3}\right)$.

To enhance production and ultimate recovery from the McClean field area in the eastern Paradox Basin, Colorado, the following drilling, development, and production practices should be employed: before penetrating the overpressured Desert Creek zone during drilling operations, increase the mud weight to 12.5 pounds $(5.7 \mathrm{~kg})$; centralize treatment facilities; mix produced water from pumping oil wells with non-reservoir water and inject the mixture into the reservoir downdip to reduce salt precipitation, dispose of produced water, and maintain reservoir pressure, creating a low-cost waterflood.

\section{ACKNOWLEDGMENTS}

Funding for this ongoing research was provided as part of the DOE Preferred Upstream Management Program (PUMP II) of the U.S. Department of Energy, National Petroleum Technology Office, Tulsa, Oklahoma, contract number DE-FC26-02NT15133. The Contracting Officer's Representative is Rhonda P. Lindsey.

Jim Parker and Vicky Clarke of the UGS prepared the figures. This report was reviewed by Dave Tabet and Mike Hylland of the UGS. Cheryl Gustin, UGS, formatted the manuscript.

\section{REFERENCES}

Castle, J.W., 1990, Sedimentation in Eocene Lake Uinta (Lower Green River Formation), northeastern Uinta Basin, Utah, in Katz, B.J., editor, Lacustrine basin exploration - case studies and modern analogs: American Association of Petroleum Geologists Memoir 50, p. 243-264.

Colorado Oil and Gas Conservation Commission, 1985a, Combined top of Desert Creek zone structure and effective porosity map, McClean field, Montezuma County, Colorado: Cause No. 435, Exhibit no. 4, scale: 1 in. =2,000 feet.

---1985b, Reservoir fluid studies, McClean field, Montezuma County, Colorado: Cause No. 435, Exhibit no. 6, 15 p.

---1987, Transcript of hearing proceedings: Cause No. 435, p. 1-6. 
Energy Information Administration, 2001, U.S. crude oil, natural gas, and natural gas liquids reserves - 2000 annual report: U.S. Department of Energy DOE/EIA-0216 (2000), p. 20.

Hintze, L.F., 1993, Geologic history of Utah: Brigham Young University Studies Special Publication 7, $202 \mathrm{p}$.

Matheny, J.P., and Longman, M.W., 1996, Lower Desert Creek reservoirs in the Paradox Basin - examples of phylloid algae filling depositional lows related to salt dissolution, in Longman, M.W., and Sonnenfield, M.D., editors, Paleozoic systems of the Rocky Mountain region: Society for Sedimentary Geology (SEPM), Rocky Mountain Section, p. 267-282.

Mickel, E.G., 1978, McClean, in Fassett, J.E., editor, Oil and gas fields in the Four Corners area, v. I: Four Corners Geological Society, p. 146-147.

Schuh, M.L., 1993a, Red Wash, in Hill, B.G., and Bereskin, S.R., editors, Oil and gas fields of Utah: Utah Geological Association Publication 22, non-paginated.

---1993b, Wonsits Valley, in Hill, B.G., and Bereskin, S.R., editors, Oil and gas fields of Utah: Utah Geological Association Publication 22, non-paginated.

Utah Division of Oil, Gas and Mining, 2002, Oil and gas production report, December 2002: non-paginated.

---2003, Oil and gas production report, February 2003: non-paginated. 